\title{
The Translation Habitus of Contemporary Basque Writers
}

\author{
Miren IBARluZea SANTisteban \\ Universidad del País Vasco \& Université Sorbonne Nouvelle Paris-3 \\ miren.ibarluzea@gmail.com
}

Recibido: 4 de noviembre de 2014

Aceptado: 25 de marzo de 2015

\begin{abstract}
Basque writers have many ways of approaching translation: some Basque writers are selftranslators, while others prefer professional translators to translate their work; some Basque writers work as professional translators, while others translate as a training activity; some of them even integrate translations and translator characters into their works of fiction. The aim of this paper is to describe what translation habits Basque writers have, and what their attitude is towards Basque translations. For that purpose, fifteen questionnaires have been analysed and the translation habitus described. Basque writers feel that translation is a very proximate reality and approach translation as authors, not as translators (it is not always the case). They do not consider themselves as being part of the professional translation field, but they perceive the evolution of Basque literary translation to be positive. The institutionalisation process happening in the field has had its effect on their approach to translation and their discourse on it. The evolution of fictional translators is a clear example of it.
\end{abstract}

Keywords: Literary translation, Basque literature, self-translation, translation habitus.

El Habitus traductológico en los escritores vascos contemporáneos

\section{RESUMEN}

Los escritores vascos contemporáneos interactúan de diversas formas en el campo la traducción: algunos autotraducen sus obras, otros prefieren que la traducción sea realizada por traductores profesionales; algunos son traductores de profesión, otros traducen como actividad complementaria o de aprendizaje; incluso hay quien introduce a traductores como personajes en sus obras de ficción. El presente trabajo pretende describir los hábitos de traducción de algunos escritores vascos contemporáneos y sus actitudes en torno a la traducción al/del euskera. Para ello, se analizan quince cuestionarios y se describe el habitus traductológico: la traducción es para los escritores vascos una actividad cotidiana; abordan sus traducciones desde la perspectiva de creación (no siempre resulta así). Sin embargo, no se sienten parte 
del colectivo de traductores. Los escritores contemporáneos vascos valoran positivamente la evolución de la traducción literaria en lengua vasca, y la institucionalización de dicha actividad ha influido en su discurso y sus prácticas; el cambio de imagen del traductor en ficción es un claro ejemplo de ello.

Palabras clave: Traducción literaria, literatura vasca, auto-traducción, habitus traductológico.

Summary: 1. Introduction. 2. A brief history of Basque translation. 3. The translation habitus of Basque writers. 3.1. Linguistic habits (or the initial habitus). 3.2. Basque contemporary writers' professional involvement with translation. 3.3. Experiences with translation. 3.4. Perceptions and thoughts about Basque translation. 3.5. Translation in fiction. 3.6. Metaphors used by writers when talking about translation. 4. Conclusion. 5. Annex: Questionnaire.

\section{Introduction}

In this paper I will try to explain how Basque translation has changed in recent decades and how this fact influences multilingual contemporary writers' work and discourse. Firstly, I will briefly explain my theoretical basis, then, I will give some data about the history of Basque translation and, finally, I will present the conclusions to the research I have carried out with various contemporary writers regarding their approach to translation.

In terms of cultural and linguistic diversity and power, it is important not to forget that there is no possibility of equal status for two languages in contact with one another, either in a geographical territory or in one's mind. The way in which we use one or more languages usually depends on socio-political and economic powers as well as on personal and biographical habits. Cultural and linguistic diversity is an everyday pattern in the Basque Country, but the Basque language is a minor (and minority) language that cohabits with Spanish in the southern area of our territory, and with French in the northern area. It also cohabits with all those languages brought by people who come from all over the world and with the languages that we learn due to globalization and/or because of personal interest. I consider a community where diverse languages and cultures cohabit to be a "translation area per se", a natural translation area: we all are translators in some way, and so are our writers.

For the purpose of this discussion, we should recall the ideas of Even-Zohar, who argues in his paper "The Position of Translated Literature within the Literary Polysystem" (1978) that the model of any literary system should include translated literature. Even-Zohar explains that no observer of the history of any literature can avoid recognising as an important fact the impact of translations and their role in the synchrony and diachrony of a given literature. Furthermore, Even-Zohar defines the circumstances in which translation may take on particular importance. He points out that well-established systems translate less than systems undergoing change or revival. He suggests that historical situations determine the quantity and type of translations undertaken, and the status of those translations is greater or lesser depending on the position of the receiving culture (Even-Zohar, 1978). 
In recent decades, a power shift has taken place within the discipline of Translation Studies, which is an evolution from the manipulation school and cultural turn that took place in the 80's and 90's. Gentzler and Tymozco consider in their co-edited book Translation and Power that power is not only a form of repression, but it must also be considered as a motivating factor in cultural domains (Nergaard, 2005).

From this understanding, this paper will demonstrate that while Basque translation as a field has been developing and becoming institutionalised over recent decades, and while translation has gained place and power, the approach of Basque writers to translation and their discourse on it have changed.

\section{A brief history of Basque translation}

Translation has always played an important role and has always been present. The first translation was published in 1571 when Joanes Leizarraga translated the New Testament into Basque. The number of translations has varied at different stages of history, as have its functions.

It was at the beginning of the 20th century that a new translation era began in Basque literature with writers such as Orixe, Lauaxeta, Zaitegi, Ibiñagabeitia, Larrakoetxea and Aresti. It was at this time that literary texts started to be translated. In fact, before, most translations (as well as most published books) were religious texts and the most important concern when translating religious texts was retaining a fidelity to God's voice. That is why Jaka defines this new era as "the free translation era" (Jaka, 2005), an era when writers such as the aforementioned contributed to the literary translation corpus, translating, for instance, classical writers (Euripides, Horace, Ovid and Virgil) and other important authors (Shakespeare, Cervantes, Longfellow, Wilde, The Grimm Brothers and so on).

This "free translation era" continued until the 1960s when a new generation of Basque writers started to take a different path in literature and translation, with authors such as Azurmendi, Txillardegi, Saizarbitoria, and some time later, Atxaga (Jaka, 2005). The end of Franco's regime (1975) marked a turning point in Basque literature and translation: the Basque language became co-official in the Basque Autonomous Community and it was used from then onwards in public education, administration and the media. New publishing houses were created, literary production increased, and the first translation school appeared (Martuteneko Itzultzaile Eskola, 1980). There was a renewed need for translation, and it was then, under those conditions, that a proper context for translation was created. It "continued to gain in importance during the last years of the 1980's and the early 1990's, making up $43.6 \%$ of the overall literary production in 1993" (Jaka, 2005). It was during this period, in 1987, that the EIZIE (The Association of Basque Translators, Interpreters and Correctors) was founded.

As a result of these new circumstances, the volume of translation continued to grow and in 2000 a degree in Translation and Interpreting was first offered at the EHU-UPV (University of the Basque Country). Research projects, such as my own, are a direct product of this institutionalisation of Basque translation. Over the last 
three decades, many projects and grants have been allocated by public institutions in order to support the Basque language and Basque translation. For instance, 160 books in the Literatura Unibertsala collection have been edited since 1990 by the Basque Government and the EIZIE; books in which not only the work conditions for translation and the quality of the product has been assured, but in which the visibility of the translator has also been stressed in the paratext. A biography of the translator is included in each work and it is the translator who writes the introduction ${ }^{1}$. The visibility of translation emerges: press reviews and public awareness of translation increased (Ibarluzea, 2011), as well as interviews with translators in the media ${ }^{2}$ and blogs about translation. Some publishing houses have created new collections for translated books, and there are even some small publishing houses which publish only translated works. A grant for translating the Nobel Prize winner's work is awarded annually (except for this year: it has not been organised because of financial constraints, which is indicative of the importance of economic power in translation). Another example of the new status of Basque translation is the Spanish National Award for Translation 2014, which was won by Josu Zabaleta, a Basque translator. The jury recognized him as one of the pioneers of Basque literary translation as well as for having created and used new literary and poetic registers in Basque ${ }^{3}$.

What seems obvious is that translation has made an enormous contribution to the development of the Basque language and literature. It has helped, for instance, to create a literary language register. In contrast, translation from Basque is not yet a very fertile field, although it is growing in quantity and quality.

\section{The translation habitus of contemporary Basque writers}

In this following section, I will discuss contemporary Basque writers' use of, experiences with, and attitudes towards, translation. Some Basque writers are selftranslators, but there are also writers who prefer to use professional translators. So self-translation is by no means the only way in which Basque writers are connected to translation: some of them work as professional translators, others translate for linguistic and stylistic training purposes, and they even integrate translation and translator characters into their works of fiction. Whatever the approach, studies have shown that translations are not equally received when performed by writers (Ibarluzea, 2011), and this fact, naturally, affects their approach when translating in addition to affecting the critics' and readers' responses to these works.

The purpose of this research is to assess the perception of translation as well as social attitudes towards it. Carol Maier (2007) estimates that public perception of translators depends on three sources of information: representations in fictional works (films

${ }^{1}$ For an analysis of the collection see Ibarluzea 2013a. For an analysis of the prefaces to the collection see Ibarluzea 2013b.

2 These can be accessed via the EIZIE's web-page.

${ }^{3} \mathrm{http} / / /$ cultura.elpais.com/cultura/2013/12/09/actualidad/1386591735_451523.html 
and literature), autobiographical materials (memories and comments on their art) and non-fictional documents (press kits, reports, biographical research...). So, for the purpose of this research, I have interviewed fifteen contemporary writers and I have analysed their work as well as written documents and interviews.

Furthermore, I have studied their habitus, which Bordieu (1992) defines as the system of durable and transposable dispositions through which an individual thinks and acts according to his or her life conditions and social trajectory. However, habitus is not only linked to the perception that a professional translator has about his or her field: the social or generalized habitus has to be taken into account too, especially when the field is not differentiated or is weakly differentiated. Meylaerts explains this in her article "Habitus and Self-Image of Non-professional Literary Translators in Minority Cultures":

Among other cases, this transposition of dispositions is very plausible in the case of authors who combine their pen with literary translation activities without being trained as translators (see also Sheffy 2005). If in addition these literary authorstranslators happen to be native translators (Toury 1995: 241) it is likely to expect dispositions related to their larger life conditions and social trajectory being part of their translator habitus. The native's competence indeed is mainly the result again not of formal translator training but of a broader socialization process: being born in a bilingual family or living in a diglossic society and being educated in a language other than the mother tongue etc.

(Meylaerts, 2013: http://v2.educonv.com/docs/index-256734.html)

Based on research projects such as those of Bassnett, Shela-Sheffly, Janis, AhitKochavi, Meylaerts and Simenoni, I drew up a twenty-item questionnaire. The questionnaire included questions about language acquisition, studies and professions, translation experiences and reflections on translation (the full questionnaire can be found in Annex 1).

I then interviewed the writers and elaborated upon their answers using additional data from interviews and papers. Finally, I categorised the findings into the following six sections: 1) Linguistic habits (or the initial habitus) 2) Basque contemporary writers' involvement with translation 3) Experiences with translation (selftranslation and co-translation, translating other authors' texts, reading translations) 4) Perceptions and thoughts about Basque translation; 5) Translation in fiction 6) Metaphors used by writers to talk about translation.

The fifteen writers (five women and ten men) ${ }^{4}$ were all born between 1947 and 1975. Therefore, they developed their literary careers after the aforementioned turning point in Basque literature: the end of Franco's regime.

\footnotetext{
4 These are the 15 writers who accepted to take part in this research project, all of them relevant examples of the current literary canon: Arantxa Urretabizkaia, 1947; Mariasun Landa, 1949; Bernardo Atxaga, 1951; Aurelia Arkotxa, 1953; Joseba Sarrionandia, 1958; Itxaro Borda, 1959; Jon Alonso, 1958; Miren Agur Meabe, 1962; Xabier Mendiguren, 1964; Iban Zaldua, 1966; Kirmen Uribe, 1970; Ur Apalategi, 1972; Unai Elorriaga, 1973; Julen Gabiria, 1973; Harkaitz Cano, 1975.
} 


\subsection{Linguistic habits (or the initial habitus)}

In terms of their general linguistic acquisitions, there are two generations of writers in our corpus: firstly, those who studied in Spanish or French but developed their literary career in Basque. Secondly, those who studied in Basque at school, which is the case of the writers born after 1965 in our corpus.

From a diathopic point of view, three of our writers come from the French-Basque area (Aurelia Arkotxa, Itxaro Borda and Ur Apalategi), whereas the rest are part of the Spanish-Basque linguistic and cultural environment. Although the language-pair changes, the Basque language is the minority language in the two societies.

All fifteen writers write in Basque. There are some writers who sometimes write in both of their languages. Nevertheless, literary bilingualism is not very common among Basque writers in comparison to Galician and Catalan writers (Manterola, 2011).

For those writers in the first generation defined above, writing in Basque was a political choice in a sense, and they are aware of having created the contemporary Basque literary corpus. In contrast, for those writers who have studied in Basque, the use of the language in a literary register was not as much a choice as a more natural occurrence. Even so, almost all of the writers cite their language skills in both languages (Basque and Spanish or Basque and French) when asked about the reasons for translating their own works.

\subsection{Basque contemporary writers' professional involvement with translation}

Susan Bassnett asserts that "today, writers tend to be more overt about the importance of translating in their lives" ". This point can be emphasised when considering our fifteen writers.

In general, they have a close relationship to translation. Bernardo Atxaga states ${ }^{6}$ : "to be in culture is to be in translation", while Aurelia Arkotxa asserts: "translation is part of creation" . Joseba Sarrionandia informed us that "we all are translators, there's translation in every communication activity" . Itxaro Borda concluded: "In the end I'm only translation" ". Jon Alonso and Julen Gabiria are professional translators: their main vocation is translation. Xabier Mendiguren is a professional editor, which links him closely to translation: he corrects and reads many translations within his job. Other types of involvement are also present. For instance, university lecturers Mariasun Landa, Aurelia Arkotxa, Iban Zaldua and Ur Apalategi all men-

${ }^{5}$ Liçons Inaugurals curs 2006-2007, Universitat Pompeu Fabra.

${ }^{6}$ Note that the fifteen writers answered the questionnaire in Basque. The quotations have been translated from Basque into English for this article.

${ }^{7}$ Unpublished interview: Bernardo Atxaga (05-08-2013).

${ }^{8}$ Unpublished questionnaire responses: Aurelia Arkotxa (08-2013).

${ }^{9}$ Unpublished questionnaire responses: Joseba Sarrionandia (08-2013).

${ }^{10}$ Unpublished questionnaire responses: Itxaro Borda (08-2013). 
tion translating lecture notes and articles among their activities. Furthermore, literary and economic reasons also link writing to translation.

Therefore, all of these writers are linked to translation. However, when asked whether they also considered themselves to be translators, only those who are professional translators considered or defined themselves as such. Joseba Sarrionandia, for instance, stresses the difference between professional and the non-professional translation: "I don't consider myself to be a professional translator, but I do think we are all translators"11.

With regards to being part of the professional field and their acquisition of translation skills, the answers to the questionnaires show that none of the writers interviewed is a member of the EIZIE, whereas ten of them are members of the EIE (the Basque Writers' Association), and none of them have studied translation formally. Aurelia Arkotxa's case may be exceptional, since her approach to translation has also been academic (she conducts university-based research on translation).

What do Basque writers know about the Basque translation field? Do writers discuss their translation experiences with translators? Do they feel that they are part of the translation world? Only half of these writers answered that they knew about the field of translation studies, and most of them say they know some translators. However, they do not seem to know about the translation field to any great extent.

To conclude, we can surmise that Basque contemporary writers feel that translation is an important aspect of their work. However, generally speaking, they consider translation to be more of a writing activity and a consequence of their being multilingual, rather than their actual vocation. Simply put: they do not consider themselves as part of the Basque professional translation field.

\subsection{Experiences with translation}

\subsubsection{Self-translation and co-translations}

All of the writers whom I interviewed have translated their own work except for Jon Alonso. It is significant that he is a professional translator, and, even so, he does not translate his own texts: "translating one's own texts is providing versions, not translating" he asserts ${ }^{12}$. Xabier Mendiguren has translated his own texts when there were no funds to pay a translator to do so, but he prefers translators to do the job.

However, in general, Basque writers have preferred not to lose control of their texts. It is precisely the word "control" that they use when talking about the subject. The reasons mentioned by the writers to explain why they translate their own texts are the following: financial issues, delays, having the skills in the two languages and the opportunity to provide an improved version or to recreate the text.

${ }^{11}$ Unpublished questionnaire responses: Joseba Sarrionandia (08-2013).

12 Unpublished questionnaire responses: Jon Alonso (08-2013). 
The reasons as to why they choose not to translate are varied. Mariasun Landa mentions length, for instance: she usually translates her short texts, but the novel she wrote for adults in Spanish was translated into Basque by a translator. Nevertheless, she always re-reads and corrects the target text when she knows the language. The other writers do the same: they read the translations and then suggest changes when they know the target language.

When talking about self-translation, Mariasun Landa states that she feels "freer" now than when she started to translate her own texts, and that translation has helped her to be more conscious of her sense of authorship. Atxaga self-translated his first texts and in his opinion it is very important to take into account the chronology of Basque literature: "in the Basque Country, at the beginning, there were no professionals who could do the job"13. Now his texts are translated by translators. Ur Apalategi goes step further still: "I prefer to spend my time creating instead of translating. I think it was not a good thing for Basque literature that self-translation became systematic: it is a political and ethical question" he explains ${ }^{14}$. This feeling is shared by Harkaitz Cano and Kirmen Uribe. Cano admits he is much more a translator now than before in his translation procedures, and Kirmen Uribe, who has only translated his poems (his first published works), argues that giving the task to translators is a way to promote the maturity of Basque literature and the professionalisation of the translation field. When discussing his self-translations, Kirmen Uribe asserts: "I don't like free versions. I think the poem has its moment, and the translator (either me or someone else) has to respect that moment"15.

Therefore, we can conclude that, globally there is a movement towards choosing professional translation. Younger writers evidently feel more comfortable with it. Even Unai Elorriaga, who defends self-translation as the only way to assure a good version, will be working with a translator on the translation of his next work. Thus, here we have, once more, some evidence of the perception and acceptance of professional translation: an indicator of the institutionalisation of Basque translation.

When talking about translators' work on their texts, writers commonly cite the fact that they do not recognise their own voice in the translation, and in some of the cases the translated versions have not even been published.

Another aspect of their relationship with translation which our writers continuously stress is the need to work closely with the translator. This relationship with the translator seems to be important for our writers: answering translators' queries seems essential to some of them. Furthermore, the writer-translator relationship is also perceived to be important for an additional reason. For Kirmen Uribe, the translator is the one who opens the door to other systems for the writer, he states that "he can do more than a literary agent"16. Professional translators are seen also as literary agents. Passing into another literary system, being translated, is considered to be

\footnotetext{
13 Unpublished interview: Bernardo Atxaga (05-08-2013).

14 Unpublished questionnaire responses: Ur Apalategi (08-2013).

15 Unpublished interview: Kirmen Uribe (12-09-2013).

16 Unpublished interview: Kirmen Uribe (12-09-2013).
} 
a real accolade by some of our writers. Arantxa Urretabizkaia recounted an interesting anecdote: "I used to merely be considered as a female writer in the Basque language, but ever since my work has been translated, I have been considered as a Basque writer"17. Thus, translation can also change the status or the position of a writer at a social and personal level.

\subsubsection{Translating other authors' texts}

Unai Elorriaga's translation of Adam Bodor's Artzapezpikuaren bisita ${ }^{18}$ was one of the stimulus for this research project. In fact, it was when I read this book that I asked myself whether an editor could have chosen this book and offered it to a professional translator. In this case it was the writer who decided to translate the book and then offered the translation to the editor. I wondered this was a common procedure.

There is no doubt that writers' selections often reflect their personal affinities and responses. To quote Susan Bassnet:

When a writer takes the time to translate something written by another writer, there is always a good reason for such a decision, whether it is to experiment with alternative modes of writing or to try and push the boundaries of one's own style. Or it may simply be that the text a writer is translating at any particular time is one that he or she wishes they could have written in the first instance, in other words, translating that work is a logical next step in one's writerly development.

(Susan Bassnet: Liçons Inaugurals curs 2006-2007, Universitat Pompeu Fabra).

In the sample of fifteen writers, all of them, with the exception of Arantxa Urretabizkaia, have at some time translated someone else's literary works.

Aurelia Arkotxa and Joseba Sarrionandia use translation as a literary creation form, whereas other writers use translation as an exercise. Translation is for Kirmen Uribe, Unai Elorriaga, Itxaro Borda and Harkaitz Cano a learning activity, a linguistic exercise. It should be pointed out that when their translations have been published, it was they who chose the texts, and in many cases they suggested the translated text to the editor for publication.

In some other cases, it happens the other way round: an editor proposes a text for the writer to translate. Work or financial motivations are also behind translating other people's texts.

Whatever the case, it seems that critics always underline the fact when it is a writer that has done the translation, as we have demonstrated in previous papers (Ibarluzea, 2011), the fact that they are writers is always emphasised.

When asked whether they use the same procedures for translating their texts and anyone else's texts, they all agree that they feel freer when translating their own texts.

17 Unpublished questionnaire responses: Arantxa Urretabizkaia (08-2013).

18 The Archbishop's Visit. 
To conclude, with regards to their translation experiences, contemporary Basque writers do approach translation from the point of view of their writing activity. When they decide to translate other people's texts, there is always a literary (and sometimes financial) reason for doing so (except, of course, for those who are professional translators).

Reflexion about translation can often be found in our writers' habitus. Papers, texts, conferences, public events, etc. are other ways to express their thoughts and perceptions about translation. They all have written reviews, articles or texts about their translation experiences in the press, book prologues or Senez (the EIZIE's annual publication). Some of our writers have also presented written papers on translation or have participated in conferences, workshops or debates. Some of them have also taught translation (Aurelia Arkotxa, Xabier Mendiguren, Unai Elorriaga and Julen Gabiria).

\subsubsection{Reading translations}

When reading translations, seven of the fifteen writers admit that they usually read (or try to read) books translated into Basque. This is certainly the case with Bernardo Atxaga, Jon Alonso, Itxaro Borda, Iban Zaldua, Unai Elorriaga, Harkaitz Cano and Julen Gabiria. Most of them are among the youngest, which is an indicator of the increasing normalisation of the Basque language and Basque translation field. Arantxa Urretabizkaia states that "I started to read translations into Basque years ago, but they seemed very artificial to me"19. This contrasts with Kirmen Uribe's experience: "I usually read more translations in Basque than literature created directly in Basque" ${ }^{20}$. Furthermore, he adds: "when writing my last book, some of those translations were on my working table. I consulted them while writing" ${ }^{21}$. In fact, it seems that the perception of Basque translation has improved over the time among Basque writers. Unai Elorriaga and Harkaitz Cano highlight the fact that several literary registers have been developed due to translation and that translations are sources of solutions in their writing processes.

We can infer from this evidence that there seems to be an increasing tendency to read translations in Basque. Jon Alonso, for example, comments that he has discovered some authors from reading their works translated into Basque.

\subsection{Perceptions and thoughts about Basque translation}

It has already been stated that Basque writers do not consider themselves to be members of the Basque translation field in a professional sense. However, since the

19 Unpublished questionnaire responses: Arantxa Urretabizkaia (08-2013).

20 Unpublished interview: Kirmen Uribe (12-09-2013).

21 Unpublished interview: Kirmen Uribe (12-09-2013). 
purpose of this research is to analyze their perception of the field, I added an item in the questionnaire about their general opinion: 20. What do you think in general about Basque translation?

Many of them (six out of fifteen) did not answer the question. Some of them said that they did not know the field well enough to have an opinion, whereas others did not wish to answer the question at all.

The remaining writers point out the evolution that Basque translation has undergone in recent decades and stress the quality of translation that has been achieved. Nevertheless, they feel that there are still some basic books that need to be translated into Basque and they also mention the problem of reception. Basque readers are not used to reading translations in Basque. The writers add that the Basque translation field is not yet well-established and that translation seems to be a militant activity rather than a professional one. Furthermore, good translations are not rewarded financially for being so and economic conditions for translating literature are not always favourable.

As far as this sample of writers is concerned, it seems that the system needs to develop further its institutionalisation.

\subsection{Translation in fiction}

As Bourdieu states, writers' contributions are very important in order for new social entities to be recognised (Bourdieu, 1992). The way in which translation and translators are depicted in Basque fictional works reflects the writers' perceptions and the societal perceptions of the activity. Delabastita and Grutman (2005) believe that there has been a "fictional turn" in translation studies as a consequence of the increase in fictional works in which translators and translation appear.

In his article "The Translator as Hero in Postmodern Fiction", Jon Thiem observes that "when not wholly invisible, we appear as marginal figures". He also states that "the translator appears as an alter ego of the postmodern writer". His research shows that the motifs that appear in fiction linked to translators are betrayal, a lack of personal identity and the vagueness of the boundary between authorship and translation (1995).

It is worth studying this phenomenon in Basque literature. In the fifteen literary writers' works, translators and translation appear in several of them.

In Izkiriaturik aurkitu ditudan ene poemak (1985), Hezurrezko xirulak (1991) and Kartzelako poemak (1992) $)^{22}$, Sarrionandia includes fictional translators in his poems. Sometimes he even presents some translated or adapted poems as original ones. When interviewed, Sarrionandia stated that this was a way to play with the concept of translation and fictionalise it.

In one of the chapters of Katebegi galdua ${ }^{23}$ (1995), Alonso includes a translation of Monterroso's famous short story When he woke up, the dinosaur was still there.

${ }^{22}$ My poems; the poems that I discovered already written; Bone Flutes; Poems from Prison.

${ }^{23}$ The Lost Link. 
Within Katebegi galdua, a translation of Monterroso's story is commissioned. Even if ostensibly it is a simple sentence to translate, it takes a very long time for the translator to do so. When he comes back with the translation, two thousand versions of it are suggested. The author informed me that this was a kind of joke, a way to mock his profession (as I have already mentioned, Alonso is himself a professional translator).

In Itzultzaile bat Parisen ${ }^{24}$ (1996) Atxaga tells us the story of a homosexual man coming to Paris to translate a book. The man does so while receiving counselling from his therapist. In a way, he wants to distance himself from his previous life and translation is a kind of therapy for him.

In Mendiguren's novel Bizitza homeopatikoak ${ }^{25}$ (2008) the main character is a woman whose relationship fails and who then decides to accept a job as a translator in the European Parliament. Again, we can see that translation is depicted as a way to break with a previous life.

Apalategi includes translation in two short stories in Fikzioaren izterrak (2010): "Bernardo eta Ramon" and "Urrezko Vespa"26. As the author himself explains, "both stories talk about literature; both are a reflection about the systemic and geopolitical situation of Basque literature, so it was impossible to omit the figure of the translator" 27 . In the first short story, a Franco-Basque translator tries to explain to an editor that Basque literature is not only just Atxaga. In the second one, there is a female translator who translates her husband's works (here the writer-translator duo of Atxaga and his wife is evidently being referenced). In one of the scenes, the two figures are changed around: the translator becomes the writer and the writer becomes the translator.

In Cano's Twist (2011) the main character Lazkano is a writer who also translates. The author states that the translator as a figure in his work is rigorous, sometimes obsessive, and that makes him interesting character in literature.

Zaldua includes translators in the book Idazten ari dela idazten duen idazlea ${ }^{28}$ (2012), in short stories such as "Itzulpengintza", "Kafkaren itzultzailea" and "Idazlea irakurlearen tailerrean" 29 . In the short story "Itzulpengintza", the author's experiences with self-translation are exaggerated: the character's translation becomes better and better when it is translated into other languages. Finally, the writer decides to translate the last version into Basque, and the result is that it is the best book he has ever written. "Kafkaren itzultzailea" is the recreation of Kafka's fictional biography, and three types of translators appear in the story. Finally, in "Idazlea irakurleen tailerrean", Zaldua's experience as a head of a book group is portrayed. As he asserts, fewer readers are present in the sessions when they discuss translations (in comparison with sessions in which Basque writers' texts are analysed).

\footnotetext{
24 A Translator in Paris.

25 Homeopathic Lifes.

26 "Bernardo and Ramon"; "The Golden Vespa".

27 Unpublished questionnaire responses: Ur Apalategi (08-2013).

28 The writer who writes while writing.

29 "Translation Work"; "Kafka's Translator"; "The writer in the reading workshop".
} 
In Uribe's Mussche (2012) the main character (who Uribe defines as a hero) is a translator. Uribe comments that it was appealing to use the translator as a character here because translators tend to be more modest, while writers are often more arrogant.

In Kristalezko begi bat ${ }^{30}$ (2013), Meabe makes a self-referential comment: she presents herself as a translator instead of saying she is a writer.

In Borda's poems "Amaren irria" (2007), "Maria Merceren (b)egia" (2011) and "Hitaz"31 (2012) translation is main theme. These poems have not yet been published, but the author read them at a conference on translation in Baiona (2013).

What we can surmise from all these fictional translators is that the translator was a marginal character before and it is now a main character; that the non-professional translator has become a professional, and that the translator is now located in the Basque Country, whereas before he or she was a character living abroad.

Several discussions about translation theory can also be found in the fictional texts: the question of fidelity, translation as a tool to access other cultures and countries, the loss of the power of the text, the relationship between writers and translators, translators' visibility, whether texts suffer or are improved when translated, etc.

It is worth looking at the publication dates of the books presented here. Five of them have appeared during the last three years, and I believe that this has a great deal to do with the institutionalisation process that the translation field has undergone in recent years. Writers are more and more conscious of translation issues now, they feel it affects them directly, and they have even created their own discourse on it. Translation is more visible now, even in fictional works.

\subsection{Metaphors used by writers to talk about translation}

The metaphors writers use to talk about translation are another kind of representation which reveal how they view translation.

The following are some of the metaphors used by the writers who have contributed to this study 32 : "translation has always seemed to me to be an act of hospitality (...) an act of opening willingly and happily the doors of a house to things which come from another house" (Landa, 2006). "Translation is surgery" (Landa, 2013) ${ }^{33}$. "Translation is a genuine cornerstone. A true keystone" (Atxaga, 2013) ${ }^{34}$. "Translation has been a way of reading and writing for me" (Sarrionandia, 2013) ${ }^{35}$. "The translator can be a bridge, a medium, a shaman. A god in his own way (...). It's a lover. (...) A large financial market. (...) A blessing (...). A way to investigate one's path. (...) A way to discover and know oneself" (Borda, 2013). "In our case translation could be a kind of therapy to establish an area of peace with the French

\footnotetext{
30 A Crystal Eye.

31 "Mother's Laugh"; "Maria Merce's Eye (and Truth)"; "About you".

32 The metaphors have been translated from Spanish and Basque into English for this article.

33 Unpublished interview: Mariasun Landa (02-09-2013).

34 Unpublished interview: Bernardo Atxaga (05-08-2013).

35 Unpublished questionnaire responses: Joseba Sarrionandia (08-2013).
} 
language" (Borda, 2013) $)^{36}$. "Translators are researchers to an extent, researchers who delve into your very soul, specialists who put themselves in other people's shoes: they are also interpreters, mediums who are able to carry the author's voice" $(\text { Cano, 2013) })^{37}$.

What we might conclude from these quotations is that translation is linked, in contemporary Basque writers' perceptions, with construction, analysis, creation and exchange. It is somehow also represented as a religion or a magical event. It is very important here to recognise that within the Basque context, where the dominant languages are more powerful than Basque, translation can even be considered a means of reconciliation with the dominant languages.

\section{Conclusion}

Having stated that in the field of translation power relations within languages and cultures play a central role in the way translation is perceived, I have shown in this paper how the evolution of Basque translation has had its effect on Basque contemporary writers' approach to translation and their discourse on it.

An institutionalisation process is happening in Basque translation, the positive reception of literary works translated into Basque is increasing and the image of the Basque translator as a professional participant in culture is emerging.

In this context, contemporary Basque writers feel that translation is a very proximate reality: they translate their own texts, they translate other people's texts, they read translations, participate in translation workshops, write about translation... but they do not consider themselves as being part of the professional translation field: they are not members of the EIZIE, they have not studied languages and translation formally in order to become professional translators. Their approach towards translation is part of their writing activity in a multilingual society. They do not use the same procedures when translating their texts and other people's, they are more and more conscious of the existence and the need for a structured translation field as well as its political and ethical implications. Furthermore, it seems that there is a tendency towards separating the activities of writing and translating, towards accepting the figure of the translator. The change in writers' discourse has also been reflected in their fiction: the representation of the translator as a fictional character has changed in recent decades. We have seen that contemporary Basque writers perceive translation to be a positive agent for exchange and for creation, which is a proof of the power of translation to build culture.

\section{Annex: Questionnaire ${ }^{38}$}

1. Are you a professional writer? If not, what is your profession?

\footnotetext{
36 Unpublished questionnaire responses: Itxaro Borda (08-2013).

37 Unpublished questionnaire responses: Harkaitz Cano (08-2013).

38 The questionnaire has been translated from Basque into English for this article.
} 
2. What relationship do you have with translation in general?

3. Have you self-translated your texts? Which ones? If yes, why did you decide to do it yourself?

4. Has someone else translated your texts? Which ones? If yes, why did you choose that option? Did you participate in the translation process? How so?

5. Have you translated someone else's texts? Which ones? Did you choose the author/text to translate? Or was it an editor who asked you to do it?

6. Is translation a writing practice in your everyday's life? Do you use it as an exercise? Why and what for?

7. Have all the translations you have done been published?

8. Would you say that you use different strategies when you translate your own texts compared to when you translate somebody else's? Do you feel that you can be freer with your own?

9. Which languages do you use in your translations? How did you learn these languages?

10. Where and how did you acquire your translation skills? Have you studied translation formally?

11. Have you participated in translation workshops?

12. Have you presented papers or given talks on translation? Have you attended others people's lectures on it?

13. Have you written any papers on translation?

14. Did any translator appear in your works? Why did you choose to do so?

15. Do you usually read literary translations in Basque? Do you usually read literary translations in other languages?

16. Do you have any relationship with Basque translators?

17. Do you know about the translation market in the Basque Country?

18. Do you consider yourself (also) a translator?

19. Are you member of the EIE? Are you member of the EIZIE?

20. What do you think in general about Basque translation?

\section{References}

Amit-Koсhavi, H., «The people behind the words, Proffesional profiles and activity patterns of translators of Arabic literature into Hebrew 1896-2009», Translation and Interpreting Studies 5:1 (2010), 41-58.

Atxaga, B., «Conferencia de Bernardo Atxaga», Vasos Comunicantes 4, (2011). Online: $\mathrm{http} / /$ /revistavasoscomunicantes.blogspot.fr/2011/03/vasos-comunicantes-numero-4.html

AtXaGA, B., «Andimaren liburu bat eskuan», Euskera 51-1 (2006), 45-49.

BASSNETT, S., «The translator as writer», paper read at Lliçons Inaugurals, curs 2006-2007, Facultat de Traducció i Interpretació Universitat Pompeu Fabra (Barcelona, 2006)

Block, H. M., «The Writer as Translator: Nerval, Baudelaire, Gide», en: GADDIS Rose, M. (ed.), Translation Spectrum: Essays in Theory and Practice. Albany: Sunny Press 1981, 116-126.

BORDA, I., «Etxetik etxera itzuliz», paper read at UEUren Baionako Udako Unibertsitateko Ikastaroak (Baiona, 2013-07-11). 
Bourdieu, P., Les reglès de l'art. Paris: Seuil 1992.

Delabastita, D. \& Grutman, R., Fictionalising translation and multilingualism, (Special Issue of Linguistica Antverpiensia New Series 4/2005). Antwerpen: Hoger Instituut voor Vertalers en Tolken 2005.

ElorRIAGA, U., «Idazlea itzultzaile», Senez 35 (2008).

ETXEBERriA, H., Bost idazle Hasier Etxeberriarekin berbetan. Irun: Alberdania 2002.

Even Zohar, I., «The Position of Translated Literature within the Literary Polysystem», Poetics Today 11-1 (1990), 45-51.

GartZia, J., «Obabakoak-en itzulpenaz», Senez 9 (1990).

Gentzler, E., «Tranlation, Poststructuralism and Power», en: Gentzler, E. \& TyMoczco (ed.), Translation and Power. Amherst \& Boston: University of Massachusetts Press 2002, 195-218. IBARLUZEA M., Literatur itzulpenaren kritika. Lehen pausoak: dibulgazio-kritikaren azterketa. Bilbo: Labayru Ikastegia eta Zornotzako Udala 2011.

IBARLUZEA, M., «Literatura Unibertsala Bildumaren bideak», Lapurdum 15 (2013a).

IBARLUZEA, M., «Literatura Unibertsala bildumako hitzaurreen azterketa», Euskera 58-2 (2013b).

JAKA, A., «Translating Basque Literature» Transcript 20 (2005). Online: http://www.transcript-review.org/en/issue/transcript-20-basque/translating-basque-literature

JÄNIS, M., «What Translators of Plays Think About Their Work», Target 8-2 (1996), 341-366.

LANDA, M., «La autotraducción como reescritura creativa», en: Traduction, Adaptation, Réécriture dans le monde hispanique contemporain, XXXII Congrès de la Société des Hispanistes Français (2005). Toulouse: Presses Universitaires du Mirail 2006, 212-227.

MAIER, C., «The Translation as an Intervenient Being», en: MundAY, J. (ed.) Translation as Intervention. London \& New York: Continuum 2007, 1-17.

Manterola, E., «La autotraducción en la literatura vasca», en: DAsilbA, X. M. \& TANQUEIRO, H. (ed.), Aproximaciones a la autotraducción. Vigo: Academia del Hispanismo 2011, 11-140.

MeYlaERTS, R., «Habitus and Self-Image of Native Author-Translators in Diglossic Societies», Translation and Interpreting Studies 5:1 (2010). Online: https://lirias.kuleuven.be/ itstream/123456789/252574/2/01mey_tis.pdf

MEYlaERTS, R., "Translators and (their) norms, Towards a sociological construction of the individual», en: Pym, A., Shlesinger, M. \& Simeoni, D. (ed.), Beyond Descriptive Translation Studies: Investigations in homage to Gideon Toury. Amsterdam \& Philadelphia: John Benjamins 2008, 91-102.

NergaARD, S., «Translation and power: recent theoretical updates», en: Buzzoni, M. \& BAmpI, M. (ed.), The Garden of Crossing Paths: the Manipulation and Rewriting of Medieval Texts. Venecia: Libreria Editrice Cafoscarina 2007, 33-45.

SElA-SHEFLY, R., «Stars or Professionals: The imagined vocation and exclusive knowledge of translators in israel», MonTI (2010), 131-152.

Sela-Shefly, R., «The Translator's Personae: Marketing Translatorial Images as Pursuit of Capital», Meta: Translators'Journal 53-3 (2008), 609-622.

SElA-SHEFly, R., \& SHLESINGER, M., «Strategies of image-making and status advancement of translators and interpreters as a marginal occupational group», en: PYM, A., SHLESINGER, M., \& Simeoni, D. (ed.), Beyond Descriptive Translation Studies: Investigations in homage to Gideon Toury. Amsterdam \& Philadelphia: John Benjamins 2008, 79-90.

Simeoni, D., «The Pivotal Status of the Translator's Habitus», Target 10:1 (2008), 1-39.

ThIEM, J., «The Translator as Hero in Postmodern Fiction», Translation and Literature 4-2 (1995), 207-218.

URKIZA, A., Zortzi unibertso, zortzi idazle. Irun: Alberdania 2006. 


\section{Basque literary works cited in the article}

Alonso, J., Katebegi galdua. Susa 1995.

Apalategi, U., Fikzioaren izterrak. Susa 2010.

Atxaga, B., «Un traductor en Paris» en AtXaga, B. ET All., Cuentos apátridas. Barcelona: Ediciones B 1997.

CANO, H., Twist. Susa 2011.

Meabe, M., Kristalezko begi bat. Susa 2013.

Mendiguren, X., Bizitza homeopatikoak. Susa 2008.

SARRIONANDIA, J., Izkiriaturik aurkitu ditudan ene poemak. Pamiela 1985.

SARRIONANDIA, J., Hezurrezko xirulak. Elkar 1991.

SARrionANDIA, J., Kartzelako poemak. Susa 1992.

URIBE, K., Mussche. Susa 2012.

ZALDUA, I., Idazten ari dela idazten duen idazlea, edo literatura gaixotasun gisa. Elkar 2012. 